\title{
Sharing Economy: Business Models and Regulatory Landscape in the Mediterranean Areas
}

\author{
Patrizia Grifoni ${ }^{1}$, Alessia D’Andrea ${ }^{1}$, Fernando Ferri ${ }^{1}$, Tiziana Guzzo ${ }^{1}$, Maurizio Angeli Felicioni ${ }^{2}$, Caterina \\ Praticò $^{2,3}$, Andrea Vignoli ${ }^{2}$ \\ ${ }^{1}$ IRPPS - National Research Council, Italy \\ ${ }^{2}$ ANCI-Lazio, Italy \\ ${ }^{3}$ CONISMA, Italy \\ Correspondence: Alessia D`Andrea, National Research Council, Italy.
}

Received: February 14, 2018

Accepted: March 19, 2018

Online Published: April 23, 2018

doi:10.5539/ibr.v11n5p62

URL: https://doi.org/10.5539/ibr.v11n5p62

\begin{abstract}
The paper describes the state of the art of the sharing economy in an ecosystemic perspective including a discussion about the strengths and weakness of business models (apartment/house renting, couch-surfing, car sharing and ride sharing, co-working, reselling and trading) and regulatory and legal issues in some European countries such as: Italy, Spain Croatia and Slovenia. The work was carried out within "open DOORS", a project was co-financed by the European Regional Development Fund.
\end{abstract}

Keywords: sharing economy, collaborative economy, business models, online platforms, peer-to-peer

\section{Introduction}

The sharing economy "has been on an exponential growth curve over the last couple of years and has been the subject of considerable interest to the stakeholders and policy-makers across the globe" (http://www.ey.com/Publication/vwLUAssets/ey-the-rise-of-the-sharing-economy/\$FILE/ey-the-rise-of-the-shari ng-economy.pdf).

The term sharing economy (often used interchangeably with collaborative economy, collaborative consumption, and peer-to-peer commerce) refers to "networks of individuals providing goods and services to each other at lower cost than getting them through corporations. It also includes individuals who share, trade, or rent products and services on an as-needed basis rather than owning them" (Rifkin, 2011). On 2 June 2016, the European Commission published a Communication containing "A European Agenda for the Collaborative Economy" in which it defined the sharing economy as "business models where activities are facilitated by collaborative platforms that create an open marketplace for the temporary usage of goods or services often provided by private individuals" (European Commission, 2016). A key component of the sharing economy is the collaborative consumption defined in Berg \& Fitter (2016) as a mechanism that balances the needs of individuals with the needs of the community. In this perspective, the traditional sharing, bartering, lending, trading, renting, gifting, and swapping, are redefined by using digital technology that is revolutionizing and mainstreaming the way people consume and share knowledge (Gata, 2015). The evolution brought about by digital technologies has taken the sharing economy concept forward and created opportunities as people can monetize their skills and suitably use underutilised resources. Digital technologies allow exploiting the production capacity potential. They enable sharing what people traditionally do not use full-time, e.g. houses and cars. They allow performing practices that promote the use and exploitation of properties promoting the re-use and access rather than purchasing ownership. But the sharing economy also has social impacts as it enriches relationships and enables a more sustainable approach to business. Indeed, the emergence of sharing platforms is changing the way industries such as food \& beverages, travel and transportation, accommodation and services carry out their business, and are forcing a debate on new business models. The sharing economy is improving the resource utilization, increasing convenience, creating new employment opportunities, improving digital awareness and environmental benefits and sustainability. It allows spreading a more flexible and convenient business model (The Economist, 2013; Koopman et al., 2015). Whereas in the conventional business models, companies are providing consumers' access to companies owned products and services, in peer-to-peer models, companies are 
facilitating consumers' access to other consumers' properties or skills and competencies. These companies generally use an online platform or a marketplace connecting consumers that have certain assets and skills with consumers temporary needing them (Andersson et al., 2013). These new business models are becoming particularly disruptive for mobility, accommodation, catering and other kinds of services, because they are able to satisfy the same needs with respect to the conventional business models, at a significantly lower price. Starting from these considerations the paper provides an ecosystem vision of the state of the art on the sharing economy including a discussion on the economic point of view as well on policies, regulatory and legal issues.

The work was carried out within the "open DOORS" that is a project on the Sharing and Collaborative economy viewed as a driver for economic, social and territorial growth in the Mediterranean regions. The project is a project funded by ERDF in the Interreg Med Programme. More info on this project is available in the following website https://open-doors.interreg-med.eu/.

\section{Related Work}

The concept of the sharing economy has been widely discussed and it has been a subject of considerable interest to stakeholders and policy-makers across the globe. Rifkin claims that "sharing economy is the third industrial revolution" (Rifkin, 2011). The sharing economy, in some experts' opinion, will replace capitalism and socialism, which characterised the nineteenth century. The term sharing economy is often used interchangeably with the collaborative economy, collaborative consumption, and peer-to-peer commerce. Neither the collaboration among individuals for the use of shared resources is a new phenomenon. The novelty of the so-called Sharing Economy lies in taking advantage of the possibilities opened by the computer technologies that advanced at the end of the 20th century. This new technological framework reduces the informational asymmetries and transaction costs (by transaction costs, economists mean all the costs and inconveniences involved in an economic transaction) that affect these activities, increases the scale at which they are carried out, and allows them to be performed in the ways that are different from those hitherto known. However, as the European Commission states: "the collaborative economy often raises issues with regard to the application of existing legal frameworks, blurring established lines between consumer and provider, employee and self-employed, or the professional and non-professional provision of services" (European Commission, 2016).

So far, the literature has provided several definitions of "sharing economy and collaborative economy", such as:

- "An economic system in which assets or services are shared between private individuals, either for free or for a fee, typically by means of the Internet." (Stevenson, 2010);

- "Networks of individuals providing goods and services to each other at a lower cost than getting them through corporations. It also includes individuals who share, trade, or rent products and services on an as-needed basis rather than owning them" (Berg \& Fawn, 2016)

- "A peer-to-peer-based sharing of access to goods and services" (Gata, 2015);

- "Any platform that brings together distributed networks of individuals to share or exchange otherwise underutilized assets. It encompasses all manner of goods and services shared or exchanged for both monetary and nonmonetary benefit" (The Economist, 2013);

- "The rental of something a user is not using such as a car, house or bicycle to stranger through a peer-to-peer service" (Koopman et al., 2015);

- "A peer-to-peer based activity of obtaining, giving, or sharing the access to goods and services, coordinated through community-based online services" (Andersson et al., 2013);

- "A socio-economic ecosystem built around the sharing of human and physical resources. It includes the shared creation, production, distribution trade and consumption of goods and services by different people and organizations" (Hamari et. al., 2016);

- "Online platforms that help people share access to assets, resources, time and skills" (Matofska, 2014);

- "An economic system based on sharing underused assets or services, for free or for a fee, directly from individuals" (Wosskow, 2014);

- "An economic model in which individuals are able to borrow or rent assets owned by someone else" (Investopedia.com, 2017);

- "A business model that actually belongs to a 'family' with multiple organizational schemes: some of them are very simple - barter - other much more sophisticated - online exchange platforms, based on complex algorithmic software" (Botsman, 2015); 
- "The use of digital platforms or portals to reduce the scale for viable hiring transactions or viable participation in consumer hiring markets (i.e. 'sharing' in the sense of hiring an asset) and thereby reduce the extent to which assets are under-utilised". (Goudin, 2016).

The above definitions indicate that the sharing economy consists of more or less informal economic activities that include consumer transactions such as swapping, renting, reselling, co-owning, lending, and donating (With et al., 2013). Different types of objects can be subject to these sharing transactions, including physical resources like cars (Andersson et al., 2013), digital resources like computer files (Benkler, 2004) and intangible goods like experience (John, 2013). These economic activities strictly rely on the use of online platforms that allow people to share their resources each other.

There are many types of actors, activities and systems in the collaborative economy. These activities can be done for profit (e.g. Uber, BlaBlaCa and Airbnb) or for non-monetary purposes (Wikipedia). Some of the companies that have flourished in this area provide consumers with access to certain goods or services through a technological platform that greatly simplifies the corresponding transactions (Zipcar). Others are merely intermediaries, also through some technological device, between the subjects who exchange or share goods or provide certain services (Uber). Some of these activities are carried out in areas that have so far lacked specific legal regulations (TaskRabbit). Others, on the other hand, are carried out in markets that have been subject to significant public intervention (e.g. in taxi and accommodation sectors), which has greatly restricted the freedom of individuals wishing to take part in them.

A more optimistic approach to the sharing economy sees it as an economic opportunity, a more sustainable form of consumption and a pathway to a decentralised, equitable and sustainable economy (Gruszka, 2017). Collaborative economy systems, however, are not without problems. They can generate negative externalities: social costs that are not borne by those who carry out these activities but by individuals, who will probably cause the level of achievement of these activities to exceed that which would be optimal from the point of view of social welfare. It has been noted, for example, how neighbours of those who make their homes available to the public on platforms like Airbnb can suffer discomfort and damage that exceeds what is normal and reasonable in neighbourhood relations. As they are typically "one-shot players" who cannot subsequently be "rewarded" or "punished" by neighbours based on their good or bad behaviour, short-term users of homes offered through Airbnb have fewer inducements than long-term users when it comes to exhibiting neighbourly behaviour.

\section{The Economic Implications}

The sharing and collaborative economy represents a new economic paradigm driven by technologies. The scientific debate around the economic implications of the sharing and collaborative economy converges around issues such as new business models, new challenges for the tax system, productive model changes, productivity growth and labour market changes. In a general approach, we can say that the sharing and collaborative economy could affect the economic dynamics in different scales. Some authors assert that the sharing and collaborative economy could have the same impact on the Western economic model (mainly based on capitalism) as the incorporation of mass production, from the organization of labour to the nature of the social contract in a capitalist society. Therefore, we are in a change of era, a transformation process in which it is difficult to predict future impacts with the evaluation tools used in the past. Other authors state that peer-to-peer business enabled by digital platforms will constitute a significant segment of the economy in the coming years. It is likely that this transition will have a positive impact on economic growth and welfare by stimulating new consumption, by raising productivity, and by catalysing individual innovation and entrepreneurship (Sundararajan, 2013). A very recent piece of research estimates that 70\% of Europeans (Apesteguia et al., 2016) and 72\% of Americans (Smith, 2016) are involved in sharing economy activities. As stated in a recent position paper published by four European consumer organizations, "although much has been written about the promise of sharing and collaborative economy and its potential benefits, it is a largely under-researched area and relatively little is known about its true impact on society, the economy, and the environment". The sharing and collaborative economy is accused of eroding labour security and generating inequality. The new sharing economy is "largely based on evading regulations and breaking the law" and subjects consumers to substandard, possibly unsafe products (Schor, 2014). As Codagnone remarks, "a number of potentially positive and negative effects can be identified in digital labour platforms. They can increase the pool of employers and workers by removing barriers and reducing transaction costs, improving matching, increasing human capital specialisation, with potential net welfare effects such as more efficient labour markets and increased employment. This may also increase productivity. However, the distributive effects are less clear, depending on whether there will be a long-tail or superstar effect. On the other hand, bias, frictions and mismatches could counter any positive effects. As they create precarious forms of employment, digital labour markets could also be the source of social risks and costs. 
Temporary work can lead to precarisation, blockages to social mobility and wage penalties. In spite of emerging indications, the evidence for these effects is still limited and not conclusive"(Codagnone \& Martens, 2016).

Finally, some collaborative economy systems and those who intervene systematically in them have been also accused of evading taxes and even social security payments, which not only undermines the interests directly protected by tax and social security legislation but also distorts competition to the detriment of 'traditional' companies operating in the same sectors that do observe the relevant legislation. Similar criticisms have been made concerning the disrespect shown for the standards established to protect the interests of consumers, users and workers. In a more limited view, it could be argued that the sharing and collaborative economy could affect existing economic ecosystems through three types of shocks:

- New collaborative or sharing projects invent a new business and therefore generate new economic activity. In these cases, the impacts will be focused on how the economic ecosystem would adjust after the shock of a new economic activity. It is in this dimension where we can analyse shifts and pressures to generate a change in the production model. In this sense, the collaborative economy can be a driver for socio-economic development through different types of innovation

- Existing collaborative products or services provided by "traditional" producers. In this case, the new supply will modify the competition conditions of the market and the impacts will be focused on the changes needed to guarantee a fair coexistence. In this case, the main economic impact could be the increase of efficiency in a context where traditional systems of production and consumption imply very high levels of underutilization of certain resources and the overexploitation of others. The case of passenger cars is paradigmatic. It is estimated that they remain parked between $92 \%$ and $96 \%$ of their useful life and that a surprisingly high percentage of urban land is devoted to this purpose. The new car sharing systems make it possible to reduce these percentages, thus reducing the exploitation of urban land, and have the potential to produce positive externalities in the fight against Climate Change and the de-pollution of our cities, since they meet the same mobility needs with fewer cars and parking spaces. The main demand is a specific legislation that takes into account peculiarities and allows a balanced approach to the multiple legitimate interests at stake, since pre-existing regulations do not always give a clear and proportionate answer to the problems posed by the widespread adoption of these models derived from the possibilities offered by modern information technologies.

- Products offered by traditional economics in regulated or restricted environments. These products would affect collaborative economy activities carried out outside the scope of the existing regulation. Such cases require a different kind of response and thus point to the need for further reflection.

\section{Methodology}

In this section we describe the methodology adopted to define the business models for the sharing economy. This discussion was based on the existing models proposed in the literature. We started from analysying many models, considering, in particular, the studies about the Internet based business models. Kalakota and Whinston (1997) classify them into two categories: Business-to-Business (B2B) and Business-to-Consumer (B2C). Timmers (1999) identified ten types of business models: e-shops; e-procurement; e-malls; e-auctions; VCs; collaboration platforms; third party marketplaces; value chain integrators; value chain service providers and information brokerage, trust or other services. Weill and Vitale (2001) offer different atomic business models: content provider; direct-to-consumer; value-net-integrator; shared infrastructure; intermediary; VC and whole-of-enterprise. Turban et al. (2002) categorize business model into three different categories: business-to-business (B2B); business-to-consumer (B2C) and consumer-to-consumer (C2C). In Focazio (2001) and Madu and Madu (2002) authors distinguish: Business to Business (B2B), Business to Consumer (B2C), Consumer to Business (C2B), and Consumer to Consumer (C2C). In the next sections we cross the business models provided by Turban et al. (2002) with the three dimensions (Platform Type, Transaction and Business Approach) that characterizes the sharing economy.

\section{Business Models in the Sharing Economy}

Being successful in the sharing and collaborative economy means building business models based on features such as trust, authenticity and transparency with your customers. Business models represent the core aspect of any company; they involve "the totality of how a company selects its customers, defines and differentiates its offerings, defines the tasks it will perform itself and those it will outsource, configures its resources, goes to market, creates utility for customers, and captures profits" (D'Andrea et. al., 2011).

In Chaharbaghi et al. (2003) three interrelated strands that form a business model have been identified: 
"characteristics of the company's way of thinking, its operational system, and capacity for value generation". Despite their generality, these three elements can be brought to a more specific level. For instance, the features of the company's way of thinking essentially pertain to a strategic dimension, while the capacity for value generation can be considered from a resource-based perspective. In Kaplan \& Norton (2004), the authors provide a useful framework for analysing businesses as profit models. The framework is based on a long tradition of classifying firms into "internally consistent sets of firms", referred to as strategic groups or configurations.

These groups are often used to explore the determinants of performance (D'Andrea et al., 2014). The "traditional" business models present an important disadvantage; they are limited by the ways customers can be reached (D'Andrea et al., 2015). Companies developed a mailing list, a brochure, a radio/television/print message that spoke to what the company believed was a typical potential customer, but often, these communications would mainly be focused on explicating the products or services the organization offered rather than being focused on the needs, and therefore, on customer benefits (Ferri et al., 2012). Moreover, the organization was offering the communication to everyone in the market in the hopes of reaching their target.

With the advent of Web 2.0 technologies, a new generation of business models for the sharing and collaborative economy has been developed. With these "new" business models, companies have the possibility of using market segmentation more effectively than ever before. Within these new business models, collaborative consumption is "made by the activities of sharing, exchanging, and rental of resources without owning the goods. This sharing economy began to spread widely by sharing the unused resources between individuals" 1 .

The type of resource was extended to intangible services and the products/objects that can be shared among companies (Business2Business - B2B) or between companies and consumers (Business2Consumer - B2C) and among consumers (Consumer2Consumer (C2C) (Cho et al., 2013).

In a study conducted by Rozin (2004), the sharing economy between companies (B2B) was defined as "collaborative activities to lend unused goods and services, which are expected to be in excess if individual companies own them, owned by a company to another one, or to invest and use the goods and services jointly with another company". Lately, this model has attracted growing interest from researchers and managers. Rozin (2004) analyse the processes and methodologies to create a global B2B brand, describing the B2B marketing strategy and using the customer's learning perspective. Recent years have seen a growing interest in research on B2C models. An important aspect is the understanding of consumer online buying behaviour in the initial and post-acceptance stages (Ferri et al., 2013; Guzzo et al., 2015, 2016). Moreover, a key element for adoption is that generally, people tend to rely on the opinion of those who are considered leaders or experts in a particular field. Furthermore, a positive testimony of other users about the products or services they would like to buy, rent or exchange is a strong persuasive element that contributes to the promotion of the sharing and collaborative economy (Ferri et al., 2008). This phenomenon is called "social influence"; it refers to changes in a person's behaviour after an interaction with other people, organizations and in general with society (Guzzo et al., 2014). Many studies have shown an increasing interest in customer retention in B2C models from diverse perspectives (González, 2003).

Finally, $\mathrm{C} 2 \mathrm{C}$ models include any transactions among consumers. Current studies in the $\mathrm{C} 2 \mathrm{C}$ field are not as extensive as the studies in B2B and B2C fields. There is a need to develop new sharing economy models that take $\mathrm{C} 2 \mathrm{C}$ into consideration. The business models that are emerging from the sharing economy are most interesting in terms of the new markets they offer to the end-users. Business models can include different platform types (business to business, business to consumer and peer-to-peer markets) related to different kinds of transactions (market, alternative and hybrid). According to the platform and transaction type, different business approaches can be identified: profit-driven, hybrid and mission-driven (see Figure 1). We adopted the definitions of market, alternative and hybrid transaction as given in https://www.shareable.net/blog/whats-a-\%E2\%80\%9Cresponsible-sharing-economy-startup\%E2\%80\%9D.

$1 \mathrm{http} / / /$ climatekoti.re.kr/kboard/user/kboard_display_main.php?abstraction=\&mode=view\&num=70spage=1\&gasi_name=\%\&gasi_code=bo $\operatorname{ard} \&$ key $1=\&$ key 2 


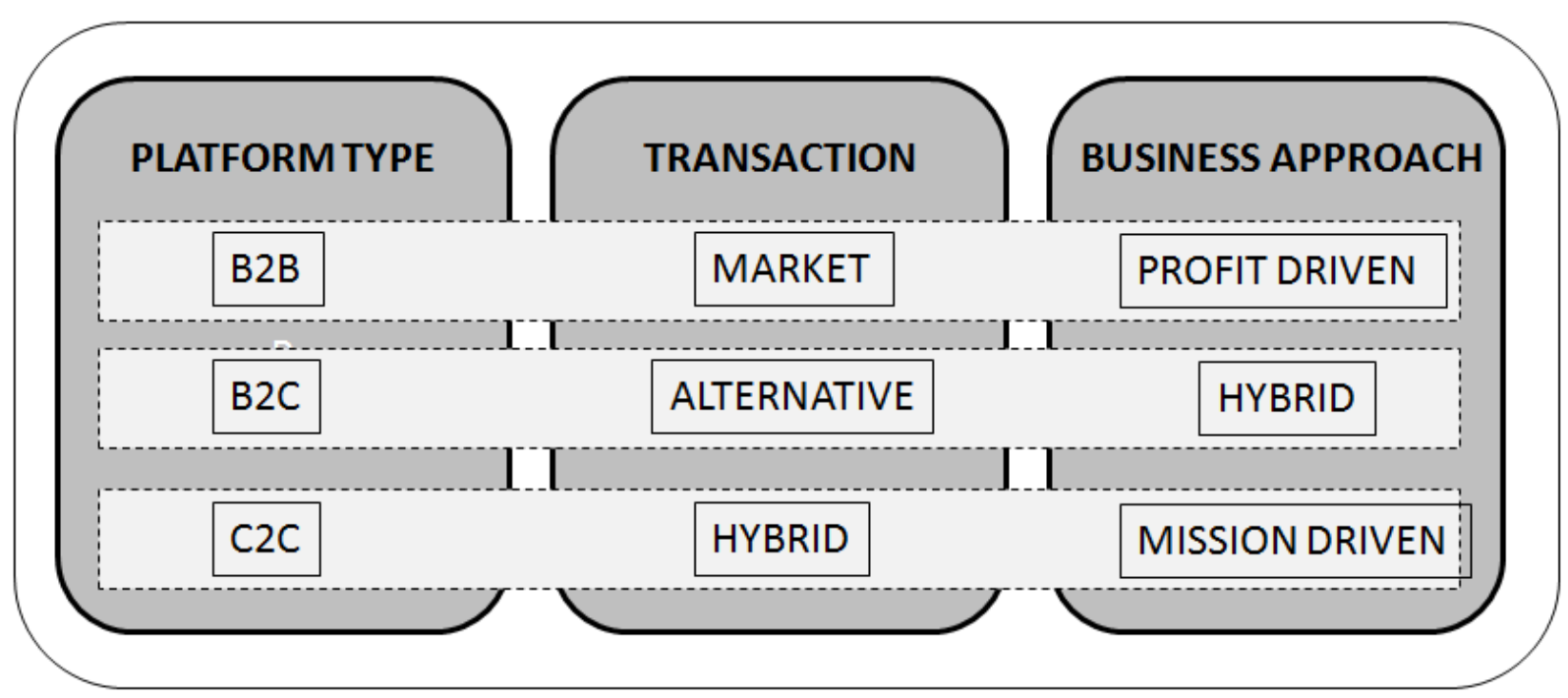

Figure 1. Components of sharing economy business models

The sharing and collaborative economy business models are set up to support collaboration between companies (B2B) to develop common strategies and find suitable business partners to accept or assign profitable orders. B2B platforms can help companies perform more efficiently and enhance their internal operations, cooperating expeditiously to generate market transactions according to a profit-driven business approach. These platforms allow companies to ensure the movement of the supply chain and the manufacturing/procuring processes.

The platform can also target the consumer. This is the case B2C platform types, developed to support companies, which perform direct sales on the Web. The B2C market is used to acquire and retain new customers with alternative transactions (sale, transfer or other disposition, directly or indirectly, including through an asset sale, stock sale, merger, amalgamation, plan of arrangement or other similar transactions) that reduce marketing costs. The aim of B2C platforms is to create alternative market transactions according to a hybrid business approach that boosts sales figures and enables cost-effective market segmentation and analysis. The main advantages of B2C platforms mainly consist in the reduction of both transactions costs and market entry barriers. Moreover, B2C platforms allow instant communication, worldwide accessibility, personalized products and services, adaptability and cooperation. However, the implementation of B2C platforms also presents disadvantages such as the reorganization of business processes, management transformation, credibility gap between technologies and business requirements.

Finally, the value proposition of $\mathrm{C} 2 \mathrm{C}$ platforms consists in facilitating e-transactions between two consumers, where one consumer offers or sells something to the other one (https://www.heropay.com/glossary/ecommerce/). While the seller needs to pay a fixed fee to sell their products, the buyer can bid without paying any fee (hybrid). The business approach is mission-driven and is aimed at introducing and normalising social practices based on values such as collaboration, sharing, improving the connection with a community. In $\mathrm{C} 2 \mathrm{C}$ platforms, sellers can post their personal items on the Internet cheaply compared to the high cost of storage space rental. Another benefit is that many small businesses can obtain a higher profitability over a $\mathrm{C} 2 \mathrm{C}$ platform compared to a physical store due to the reduction of overhead costs when conducting e-business transactions. As for the disadvantages of $\mathrm{C} 2 \mathrm{C}$ platforms, they are related to credit, payment and distribution. At present, most Internet users worry about the security of electronic payments. These different platforms have become so successful that they have started to disrupt the traditional markets. Beyond the implications for businesses, the sharing and collaborative economy could assist with broader societal change and increase the resilience of communities. The most widespread business model deployed by sharing and collaborative economy companies features an online marketplace through which the demand for certain assets or services amongst peers is matched with the ownership of those assets and services by other peers.

The next sub-section discusses some examples of B2B, B2C and $\mathrm{C} 2 \mathrm{C}$ platforms apartment/house renting, couch-surfing, car sharing and ride sharing, co-working, reselling and trading). The benefits and weakness that characterise each of them are described in detail.

\section{Apartment/House Renting}

Renting a house or apartment through an online community marketplace is an alternative to home ownership due 
to financial or time constraints. The basic idea behind this model is to connect people looking to rent their homes to people who are looking for accommodation. The new element is the speed and the scale at which the business model, together with the development of high-speed Internet, has made short-term home rentals possible. The essential elements of apartment/house renting are shown in Table 1.

Table 1. Benefits and weakness of apartment/house renting platforms

\section{ESSENTIAL ELEMENTS OF APARTMENT/HOUSE RENTING}

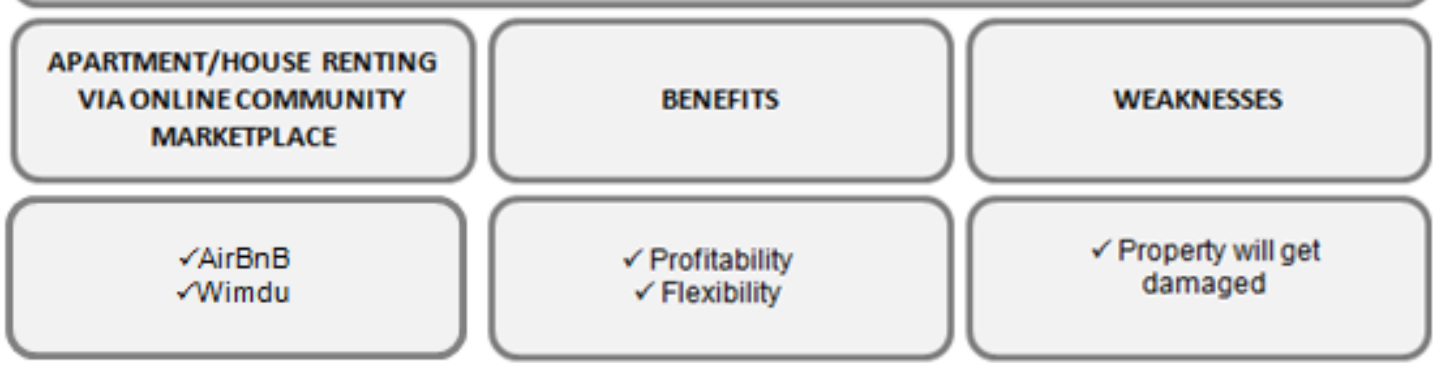

Examples of renting apartment/house through an online community marketplace are the following:

- $\mathrm{AirBnB}^{2}$ (B2C) is essentially an online platform through which ordinary people rent out their spaces as accommodation for tourists.

- $\mathrm{Wimdu}^{3}$ (B2C) is an online platform based on peer-to-peer property rental that advertises properties (from single rooms to full apartments) for short-term lettings.

These online marketplaces vary widely, ranging from a living room futon to an entire island (D'Andrea et al., 2011), but typically involve a private room or an entire apartment or house (Guttentag, 2015). It has contributed to a significant decline in the number of traditional travel agencies, which have been forced to focus more specifically on complex and higher-end purchases (Bachman, 2013; Candela \& Figini, 2012; Juman \& Quinby, 2013; Shaheen et al., 2001). The reason can be found in the advantages that this new form of renting apartment/house offers. The first is profitability; the online platform gives homeowners the possibility of renting their apartment/house for a short or long period of time without having to go through long administrative procedures. Closely linked to this is the possibility to choose the dates when homeowners want to rent out their accommodation (flexibility). Moreover, they have the freedom to choose who they rent the properties to. Another important advantage is the social aspect; in fact, hosting can facilitate the building of new friendships. Despite the benefits, there are concerns for hosts and guests. The greatest risk for hosts is that their property might get damaged. While most transactions occur without incident, there are stories of entire houses being trashed by dozens of party-goers when the online community marketplace hosts thought they were renting to a quiet suburban family, or an instance when a host came home to find his property had been damaged, items had been stolen and the place was littered with meth pipes. The main concerns for guests might be that the property does not match the description or that the host is unresponsive to their needs. Both hosts and guests can help minimize the risks by using online community marketplace features such as Host Guarantee, profiles, reviews, Verified IDs, secure payment and messaging functions.

\section{CouchSurfing}

CouchSurfing is a C2C community of over 5 million members in 97,000 cities around the world that connects travellers and locals who meet offline to share cultures, hospitality and adventures - whether on the road or in their hometowns. The idea of CouchSurfing is to bring together people from all nations of the world to promote the sharing of culture and thoughts by offering free accommodation with the bonus of the member's company and tips. The essential elements of CouchSurfing are shown in Table 2.

\footnotetext{
${ }^{2}$ https://www.airbnb.it/

${ }^{3}$ http://www.wimdu.it/
} 
Table 2. Benefits and weakness of CouchSurfing platforms

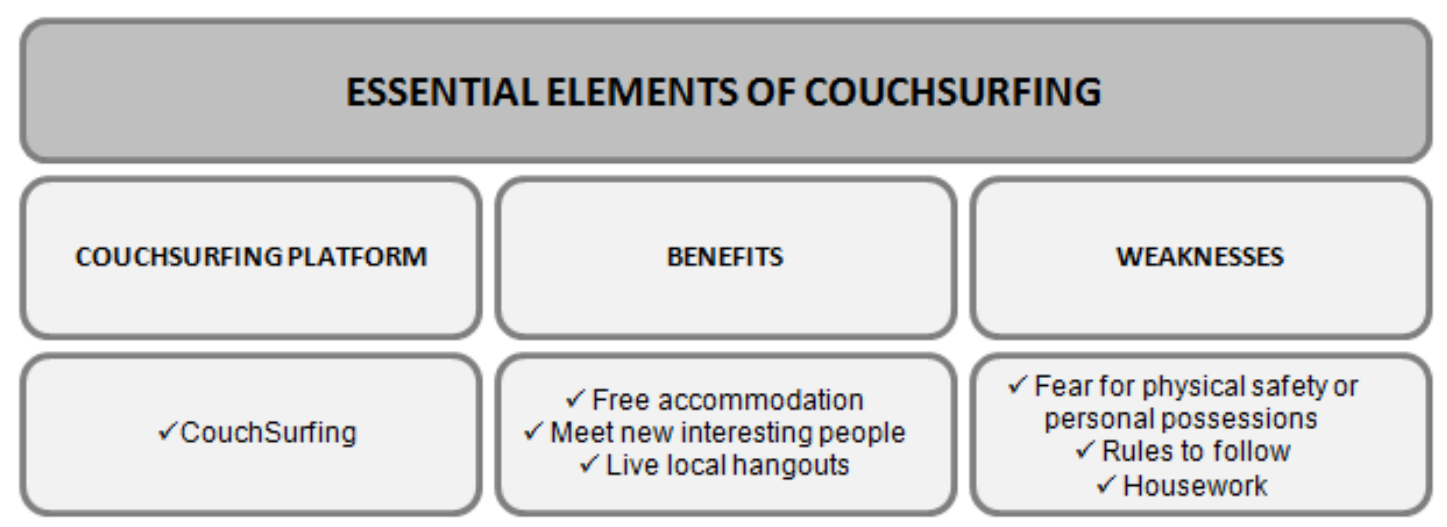

CouchSurfing provides the opportunity to meet with them, share life experiences and have fun and laugh. Learning about other cultures allows guests to become more tolerant towards other nationalities and gain personal knowledge: "when you get to experience personally you can grow as a person4". The possibility of having a temporary home away from home without monetary exchange is the fascinating aspect of Couchsurfing. Closely linked to this is the advantage to meet new interesting people, which allow guests to learn more about the culture and traditions of different places. Another important advantage is the possibility of living the local hangouts (the best restaurants, the pubs with the most "vibe") and visiting places that wouldn't make it into tourist guidebooks. Travelling is not only about ticking off all the historical sites listed in the guidebook, but also to experience different cultures, try new food and see how others go about their day to day lives. Obviously, there are a number of cons. One of the biggest ones is that people really don't know anything about where they're staying or who they're staying with. This can generate fears for physical safety or personal possessions. Moreover, the accommodations may not be as nice as initially presented (room may be small or the couch may be uncomfortable). Another disadvantage is that guests have to follow any rules set by the host. Some hosts give guests all the freedom and give them a key to let themselves in and out. Others have certain times by which guests have to be in and out of the property and certain rooms they're not allowed to use. Some hosts may also require guests to do housework (washing the dishes or cleaning the room).

\section{Car sharing and ride sharing}

Car sharing and ride sharing are new phenomena in the current economy. These examples of sharing economy aim to provide all the benefits of car ownership at a lower cost than traditional car rental or taxi services. They are prevalent in American and Canadian cities. The basic idea of car sharing is renting a car for short trips; car sharing organizations charge by the minute or by the hour, period after which the vehicle will be available for another driver. Car sharing allows drivers to find a car for their specific short-term needs. People can enjoy the advantages of private cars without the costs and responsibilities of ownership (Costain et al., 2012).

By using some services like Car2Go (B2C), it is possible to commandeer a shared vehicle, owned by a for-profit or non-profit organization, and pay for the driving time. Costain et al. in (Cohen et al., 2008) found that car sharing in Toronto was often used for off-peak travel or during weekends due to the reduction of public transportation and low traffic congestion. The concept of ride sharing is similar to the idea of a taxi. By using apps like Uber (B2C) and Lyft (B2C), it is possible to hail a ride from drivers in their personal cars.

\footnotetext{
${ }^{4}$ http://www.couchsurfing.org/about.html/mission. Quoted: 05.11.2011
} 
Table 3. Benefits and weakness of ride sharing and car sharing platforms

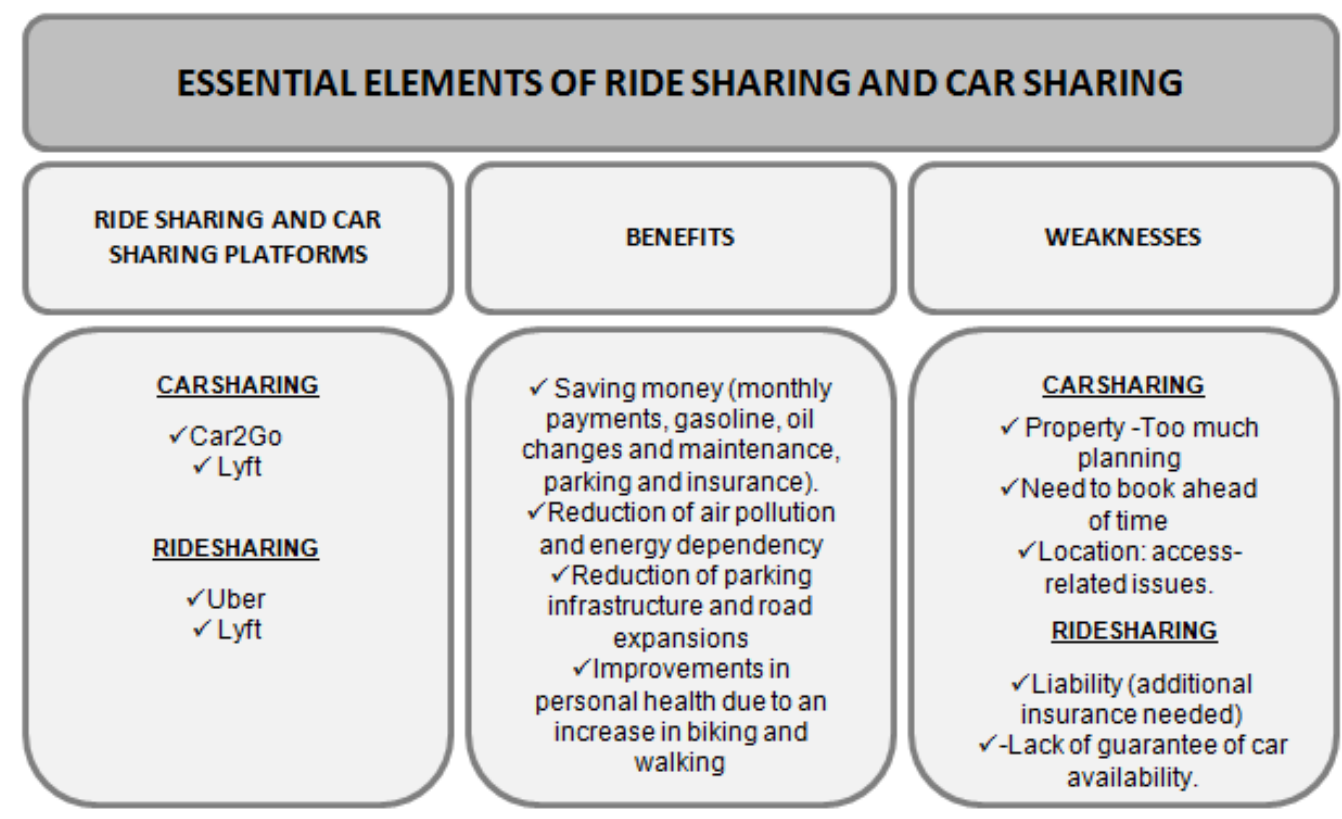

Several studies have analysed the costs and benefits of car sharing (Cervero \& Tsai, 2004; Huwer, 2004; Katzev, 2003; May et al., 2008). These studies found that ride sharing and car sharing eliminate the fixed cost associated with auto transport (e.g. purchase, registration, insurance) and reduce costs related to public transport (taxi or car hire). This new way of commuting is very useful for occasional drivers. Other benefits are the reduction of the number of cars on the road and the need for parking spaces, which can then be used to develop parks and urban green spaces (Merkel, 2015). There are also health-related benefits because people who frequently use ride sharing and car sharing tend to sell their own cars and switch to biking and walking. Depending on the circumstances, both ride sharing and car sharing can be used for commuting. However, if people live in a small town or rural area, vehicle sharing does not offer as many advantages.

There are some weaknesses in this form of sharing economy. For example, car sharing requires a lot of planning. Some people think that this process takes a lot of time and tend to look for other solutions. Additionally, the demand is high and a sometimes car sharing services are not able to satisfy all the requests, which means that it is necessary to book ahead of time. This is a disadvantage for drivers who want immediate solutions and leads clients back to car rental. Other concerns are related to location, because sometimes car sharing services are far from the clients or difficult to reach. The limitations of car sharing are at the same time the strength of ride sharing. Among the risks associated with ride-sharing services is the issue of liability. For example, if there is an accident, people in the car may be held liable for it. To avoid this type of complications, service users take out additional insurance. Another disadvantage is the lack of guarantee that a car will be available when it is needed; for example, it is difficult to find available cars on rainy days or during rush hour.

\section{Co-working}

Co-working spaces are becoming a new horizon of urban centres. They make possible to spread overhead costs among hundreds of workers in different fields. With the financial crisis of 2007/2008 and the subsequent global recession, several collaborative, shared working spaces, called co-working spaces, were born worldwide (DeBare, 2008). This tendency represents a way to share the costs of one big office space with other freelancers or entrepreneurs with perks that they might not get at home, such as conference rooms, espresso machines, phone lines, Wi-Fi connections and spaces for creating opportunities for socializing (Leforestier, 2009). Several cities have at least one co-working hub. Examples of co-working spaces are the following:

- Minneapolis-St. Paul's COCO $^{5}$ (B2B) is a destination for building ventures and exploring new possibilities in the company of other creators. It offers the membership that provides access to multiple co-working locations, meeting venues and educational and social events.

\footnotetext{
5 https://explorecoco.com/
} 
- Chicago's The Coop $^{6}$ (B2B) is a co-working space in downtown Chicago that is open year-round. It hosts freelancers, designers, small businesses and start-ups.

- Austin's Link Co-working ${ }^{7}$ (B2B) holds twenty offices of varying sizes, from one-person rooms to 15-people suites. It has common spaces, including a kitchen and a hangout spot. It offers open plan co-working, small meeting room spaces, conference room rentals, office space, dedicated desk space and event space.

Table 4. Benefits and weakness of Co-working platforms



This kind of sharing economy has several advantages for workers. Firstly, it contributes in providing an atmosphere that encourages social interaction, giving them the opportunity to meet potential partners, future collaborators and technical experts; moreover, the emotional intelligence is increased just by working together. Workers can benefit from a friendly and collaborative environment to foster their innovation and creativity (Lonoff Schiff, 2014). In addition, co-working allows impoverished start-ups to have a workplace (e.g. a desk). Freelancers and professionals can work in a dynamic environment at a relatively low cost. Costs are significantly lower than those of a small office. In some cases, these spaces also work as accelerators for exciting start-ups. There are also some disadvantages; in fact, co-working spaces are not as quiet as private offices and interruptions can always happen.

\section{Reselling and Trading}

Reselling and trading refer to forms of sharing economy that use popular marketplaces for goods, such as eBay, Craigslist and Kidizen. Sellers can obtain value from things that they do not use and buyers obtain goods at a lower cost. People can sell anything on eBay by just setting up an account, taking some pictures of the item and listing it. Another user can find the item, bid for it and buy it directly. There are other popular online auction sites where users can sell peer-to-peer (eBid.net, webstore.com, onlineauction.com, ePier.com). An example of B2B platform for professional sellers is Amazon Business. The difference among these sites is the listing fees (the prices paid to sell something). Examples of reselling and trading platforms are the following:

- eBay $^{8}$ (B2C)

- Craigslist ${ }^{9}$ (B2C) is a classified advertisements website that includes sections for personal ads, housing, jobs, and gigs, resumes, for sale, items wanted, services, and discussion forums. It started out as a small email list by Newmark, who had just moved to San Francisco.

- Citizen ${ }^{10}$ (B2C) is an online marketplace for used children's toys and clothing.

\footnotetext{
${ }^{6}$ http://coop.onedesigncompany.com/

7http://www.linkcoworking.com/about/

${ }^{8}$ http://www.ebay.com/

${ }^{9}$ https://www.craigslist.org/about/?lang=en\&cc $=\mathrm{gb}$

${ }^{10}$ https://www.kidizen.com/

${ }^{4}$ https://services.amazon.com/amazon-business.html?ld=usb2bbslpsubnav
} 
- Amazon Business ${ }^{4}$ (B2B): allows professional sellers to have a targeted way to reach business customers on Amazon. "With a full suite of tools to enable B2B ecommerce, small businesses to large enterprises will find new ways to engage professional customers in supply chain relationships".

Table 5. Benefits and weakness of reselling and trading platforms

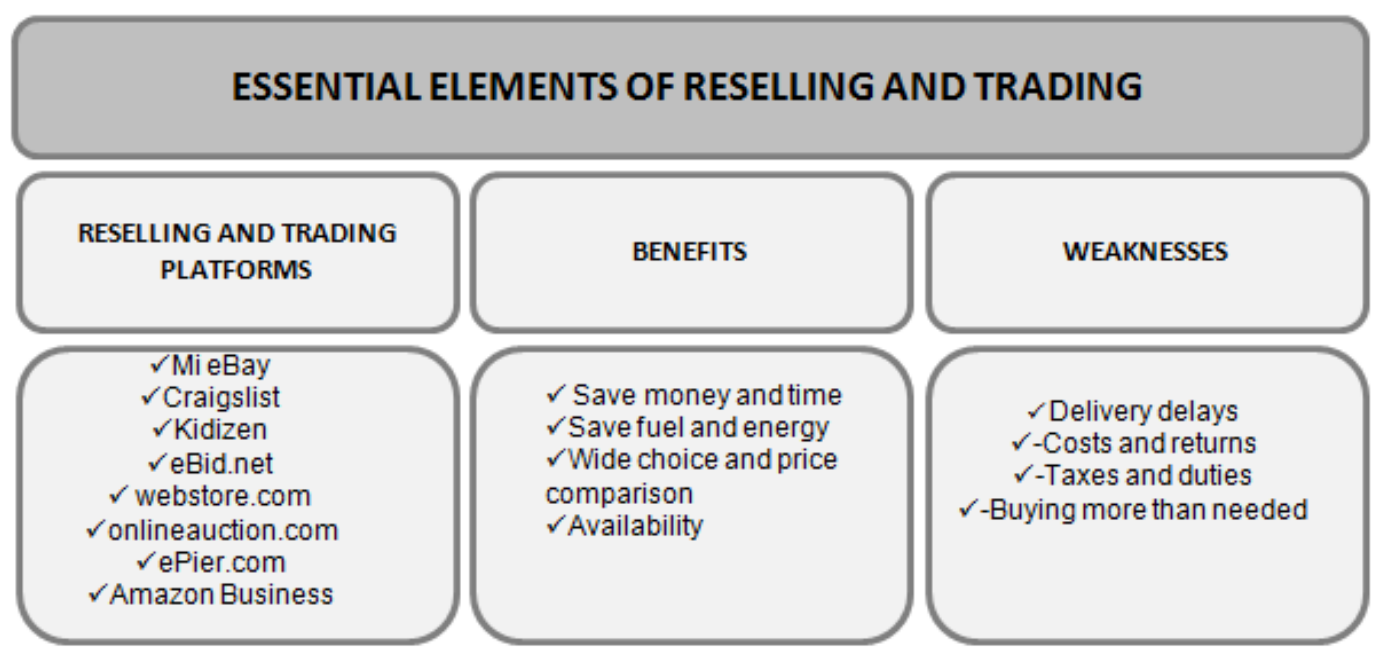

Dozens of e-commerce business owners share the major advantages and disadvantages of selling via Amazon, eBay, Etsy

(https://www.cio.com/article/2836077/e-commerce/pros-and-cons-of-selling-on-amazon-ebay-and-etsy.html).

Prices are usually cheaper on the web because there are no warehouse or staff costs. It is more convenient because people can sell at home, quickly and at a convenient time. In online shopping, there is a wide choice of products from all around the world, some of which cannot usually be found in traditional outlets. Furthermore, it is possible to easily check prices and compare them with other sites with just a few clicks. Another benefit is the availability; most internet sites offer delivery within a few days. There are also some disadvantages to online reselling. Customers can experience delivery delays since some sites still use traditional carriers. Sometimes taxes and duties for goods outside the European Community are expensive and the goods are not as cheap as they seem. Also, returning a purchase can have an added cost. Finally, there is the risk of shopping addiction. It is very easy to buy and spend more than intended.

\section{Regulatory Implications of the Sharing Economy at National and European Levels}

The economic, environmental and social effects of the sharing economy will depend on institutional changes still to come. Institutions do not only regulate activities on sharing platforms but also shape the future development of the socio-technical infrastructure that emerges as the sharing economy scales up (Frenken \& Schor, 2017). Since its inception, the EU has been in favour of the collaborative economy. In "A European Agenda For The Collaborative Economy" (European Commission, 2016), the Commission refers to the benefits that digital platforms can bring to Europe, highlighting the importance of ensuring that these platforms guarantee "fair working conditions" and remembering that they are also subject to "fiscal regulations". In fact, Neelie Kroes, Vice-president of the European Commission and European Commissioner for Competition between 2004 and 2009 , has said that the emergence of digital platforms is an unstoppable process that means greater economic efficiency, adding that going against them is a mistake. Many authors have concluded that the current regulatory framework is not fit for purpose (e.g. e-Commerce Directive). Codagnone underlies that there is a debate between proponents of self-regulation who argue that formal regulation is costly and serves to protect vested interests and the proponents of extending the reach of formal regulation to sharing platforms in order to correct market failures that private parties cannot overcome on their own. The regulatory debate and the policy responses to the challenges posed by some sharing economy platforms are very fragmented in the EU (Codagnone \& Biagi, 2016). Thus, the question that arises is how and to what extent EU rules apply to the sharing economy and whether the impact of EU law is to increase or, on the contrary, to decrease legal certainty in this field. It is certain that the EU could, through harmonization or otherwise, override national disparities and help create an internal market for collaborative economy. (Hatzopoulos \& Roma, 2017) Placing the phenomenon of the sharing economy in a legal framework is a difficult process due to its diversity, heterogeneity and propensity for change. This calls into question a number of regulatory matters and poses new questions for European-level regulators. The normative regulation of the sharing economy seems like an obvious area that can 
confer benefits. However, currently the European debate on normative regulation of sharing economy services is very fragmented; there are those radically against any intervention (Cohen \& Sundararajan, 2015; Koopman et al., 2015), those who are in favor of some form of regulation (Cannon \& Chung, 2015; Gobble, 2015; McLean, 2015; Ranchordas, 2015; Rauch \& Schleicher, 2015; Sunil \& Noah, 2015; Zrenner, 2015) and those that propose very rigorous interventions such as transportation services (Daus \& Russo, 2015) or taxes (Oei \& Ring, 2015). This deregulation can lead to serious problems for companies growing and operating across European borders. In order to solve these problems and to develop a normative regulation of the sharing economy at European-level, several major issues need to be addressed (Munkøe, 2017):

- Employees/contractors: the first crucial issue to solve is whether sharing economy providers are considered as employees or independent contractors. This is an important issue because employees have certain rights with regards to working conditions that are not considered for independent contractors.

- Business entities/private individuals: if the provider is a business entity it can meet numerous administrative and regulatory requirements. So if the sharing economy provider is an independent contractor, it is important to consider whether and under what conditions it has to be considered a business entity rather than a just private individual.

- Contractual relationship: another range of questions is about the contractual commitment between somebody (business entities/private individuals) that uses a sharing economy platform and the service provider.

- Insurance: some degree of trust can be established between strangers; in this sense sharing platforms have to guarantee their users against mishaps.

- Taxation: incomes from sharing services have to be declared and taxed; authorities have to find ways for ensuring proper oversight of these income streams.

- Externalities: a major problem is also represented by the negative externalities. In most cases, the temporary citizens are tourists that tend to be noisier than permanent residents.

In this perspective, in June 2016, the European Commission presented a guidance to support consumers, businesses and public authorities in the collaborative economy. The Communication "A European agenda for the collaborative economy" provides guidelines on how existing EU law should be applied to this dynamic and evolving sector. The main points of these guidelines are:

- To harmonize the rules of the EU countries: the aim is to harmonize the rules of the EU countries in order to have legislation in this field guided by common rules and objectives. In fact, some services like Uber have been accepted in the UK, while in other countries have been oppressed. The guidelines harmonize the various national rules facilitating companies that have to address 28 different national laws.

- To minimize the prohibitions to services like Airbnb: Brussels has criticized some measures, such as those designed by Berlin forbidding citizens to offer for rent the whole house Airbnb or similar services without prior authorization by the city administration and underlines the importance of minimizing the ban on services like Airbnb.

- Days limited to rents of houses: the Commission is in favour of soft measures, such as the introduction of limits on the number of days in which people can give for rent their own apartment or a room on sharing sites like Airbnb. Restrictions are necessary for the uncontrolled increase in rents of which it was accused the platform.

- The Uber drivers as employees. This is one the most debated point among the actors of sharing economy that must be solved. According to European Commission, it is not a commitment of Uber to set tariffs for its employees, otherwise, they would become real employees, and therefore would need to sign an employment contract with them, with all the additional costs for the company.

- Okay for the rating to increase customer confidence. Brussels is in favor on the issue of the rating, the mechanism that many platforms use to increase customer confidence. It is the same used by Uber for drivers that more are rated by customers; more are reliable and higher is their rankings.

Moreover, business authorisations or licenses should be requested only where strictly necessary and not for example where platforms act as intermediaries between consumers and those offering the service. Member States should also differentiate between people providing occasional services and providers acting in a professional capacity by establishing thresholds based on their activity. Service providers and platforms have to pay taxes like: 
tax on personal income, corporate income and Value Added Tax. Member States are encouraged to simplify and clarify the application of tax rules. The EU Member States should review and revise existing legislation according to this guidance. In response to the growing importance of the sharing economy, several European member states have looked for normative regulation of the sharing economy.

Within the "open DOORS" project four European countries are involved: Italy, Spain Croatia and Slovenia. In the following section examples of normative regulations of these countries are illustrated.

\section{Italy}

Italy is the country that has the major number of users and people aware of what is the so-called "sharing economy. The development of the sharing economy activities and projects, inspired by the collaborative economy principles, is a task of the "Sharing Italy" an Italian Sharing Economy Association (AISE) founded in 2014. The AISE offers several services for educating enterprises and workers to the use and diffusion of sharing economy solutions.

At the normative level in March 2016, the Innovation Parliamentary Intergroup presented a law proposal (the Sharing Economy Act) at the Chamber of Deputies of the Parliament, aimed at regulating the sharing economy activities. The basic idea of this law proposal is "to share goods and services, but in some cases, it has become a real business, which has to be regulated in order to protect the already existing sectors in the market". This law proposal states that all platforms have to sign up to a sharing economy registry and provide documents for the AGCM's (competition authority) approval. Another key point is the introduction of tax rates. Article 5.1 of this bill states that the incomes up to 10 thousand euros will be named as "non-professional income deriving from sharing economy" and will be taxed at a $10 \%$ rate. Incomes over $€ 10,000$ will be cumulated to autonomous or dependent working incomes, and will be taxed according to the relative tax rate. These quotas will be paid to the authorities as taxes. This allows a distinction between amateur and professional operators respecting the criteria suggested by the EU Commission.

In Italy, a strong and intense debate on the Uber application there was which led to a sentence of the Milan Tribunal affirming the illegality of UberPop. UberPop is not officially legal and it is considered not enough safe for users. Uber services have been criticized by regular taxi drivers due to a highly increased competitiveness. Rules in Italy establish that "Uber taxi drivers cannot stand in the streets and take random passengers looking for a lift, but they have to wait in arranged areas and agree by phone for the service, before taking them in the car".

\section{Spain}

In Spain, an association of sharing economy companies has been established "Sharing Espana", composed by 26 members including international ones such as BlaBlaCar and Airbnb, and also local initiatives such as SocialCar and Chicfy.

The current normative regulation of the sharing economy is determined by law 5/2011 of 29 March on Social Economy that establishes "a common legal framework for all entities in the social economy determining building measures for them". In December 2014, Uber has been banned nationally and is now trying to re-enter the Spanish market by working with drivers who carry a valid professional VTC license. In 2015, Blablacar was sued by bus companies that claimed that its drivers should be considered as commercial enterprises. In 2015 it is of major importance also the law 43 of the 9 October, which regulates the organizations of Third Sector of Social Action considered as the interlocutor with the central government. The law defines "building measures those public authorities can take on their behalf". In March 2016, the Spanish regulator (CNMC) published preliminary results of a study on the collaborative economy that recommend eliminating some "unnecessary restrictions" such as "unnecessary or disproportionate quality and security requirements" limiting the development of the collaborative economy. Some important eliminations concern: "limits on the total number of vehicles, restrictions on the territory covered by the licenses, the introduction of disproportionate amounts of compulsory insurance coverage, compulsory working hours, limited numbers of licenses per person, a ban on having different drivers per license, the need for an administrative authorisation for hired car with driver activities, and prohibitions for looking for clients in the streets". Concerning the vacation rental sector the elimination of limits concern "the prohibition on renting permanent residences or single rooms, the use of a moratorium to postpone the introduction of new apartments, the obligation to include the apartments in a registry, a minimum and a maximum number of days for renting, and limits according to the type and location of the apartment" According to the document, a users' reputation is very important in the sharing economy, in fact, it allows reducing the asymmetric information between the company and the customer. For this reason, heavy regulations for taxis and hotels are not needed. 


\section{Croatia}

In Croatia, the government of the Republic of Croatia accepted, on the 30th of April 2015, the Strategy for the Development of Social Entrepreneurship 2015 - 2020 that represents a focal point for all interested stakeholders wishing to form any organization. The legal forms of social enterprises can be: limited liability public company, limited liability private company, institutions cooperative, associations, foundations, credit union and mutual insurance company. Various activities are performed within these social enterprises such as cultural, intellectual, tourism, production, agriculture, etc. The work towards social enterprises development is complemented further by state institutions contributing to the development of public policies such as the Ministry of Social Policy and Youth, the Ministry of Labour and Pension System, the Ministry of Business and Trade and the Government Office for Cooperation with NGOs.

Regarding sharing economy related to transportation, Uber officially arrived in Croatia October 2015. In this country, Uber had no problems related to bureaucracy and perceived resistance from local taxi services, by working diligently to make its service legal in Croatia. UberPop, a service that allows owns a car to be an Uber driver, is not available in the country and it is illegal. UberX instead which only employs licensed drivers is legal.

\section{Slovenia}

The normative regulation in Slovenia presents different problems for sharing economy services mainly with respect to the tourist accommodations. A number of Slovenian laws regulating tourist accommodations are adverse to the Airbnb idea of offering accommodations to travellers. In particular, the major problems Slovenian providers are facing through Airbnb are the registration of activity and taxable rents. A proposal for modernisation of regulations suggest a simpler registration of apartments, electronic registration of guests, and electronic payment of tourist taxes, plus suspension of the time limit of five months a year (http://www.rtvslo.si/news-in-english/airbnb-in-slovenia-when-rigid-rules-hinder-occasional-business/360416).

The first response of the Ministries (Economy, Interior, Finance and Public Administration) to their initiative is encouraging. They are all in favor of the solutions which would facilitate this activity through Airbnb. On considering Uber, it wants to launch two services in the Slovenian: Uber Ljubljana the first in the world to offer rides in electric cars, and UberX, the most common service in Europe. However, the country has to update its legislation before Uber come to Slovenia. In fact, the existing one does not support Uber's business model and the Infrastructure Ministry is changing the road transport act. European Commission's recommendations on sharing economy will be taken into account when drafting the changes. According to Uber's Central and Eastern Europe director Rob Khazzam in Slovenia, only licensed drivers who will pass Uber's training will be able to drive the company. Users will call a ride via its platform with the app will calculate the cost of the ride and payments will be made with a card to prevent tax avoidance.

\section{Discussion and Conclusion}

The sharing and collaborative economy is a complex concept that appeared at the end of the 20th century and has recently become the subject of a deep social, political and academic debate. The discussions, often very controversial, focus on aspects such as its definition and classification as well as its economic and regulatory/legal dimensions. These debates range from the consideration of the sharing economy as a new disruptive paradigm that can deeply transform the economic and social model of world capitalism, to the perception that it is a new neoliberal adaptation that puts at risk the working conditions, the protection of consumers and the equality on which the European social model is based. However, there is no doubt about its growing economic importance. According to recent studies, economic activities linked to the collaborative economy show growth rates much higher than those shown by other economic sectors. Some estimates suggest that in 2015 sharing economy generated a stunning \$15 billion in revenue and it "is expected that in 2025 more than $\$ 335$ billion in revenue will be generated by the main industries in the sharing economy" (PwC, 2015).

Being successful in the sharing economy means for companies building business models that are based on features such as trust, authenticity and transparency with customers. The sharing economy business models are set up first and foremost to support supply collaboration between companies (B2B) to develop common strategies and find suitable business partners in order to accept or assign profitable orders. B2B platforms help companies to perform efficiently and enhance the internal operations, cooperate expeditiously for creating market transaction according to a profit-driven business approach. The advantage of these platforms is that they allow maintaining the movement of the supply chain and the manufacturing/procuring processes. An important disadvantage refers to their practical use, in particular, linked to the capacity of the market to adopt new technologies; in a market, where companies do not use new technologies, the application of B2B platforms is 
complicated and does not enhance the efficiency of business operations. Some examples of sharing economy business models (apartment/house renting, couch-surfing, car sharing and ride sharing, co-working, reselling and trading) are discussed in the paper underlining benefits and weakness that characterise each of them. Moreover, a discussion on policies and regulatory/legal issues are provided.

\section{Limits and Potential Future Research}

The paper proposed only a part of the study carried out in the "open DOORS" project analysisng the business models and the normative regulations of European countries involved in the project. The analysis of the business models can be improved in future researches on the basis of the geographical scale, considering experiences and platforms used at local, national and transnational level. Moreover, in the paper examples of normative regulations of some European countries (Italy, Spain Croatia and Slovenia) are being discussed. Member States are encouraged to simplify and clarify the application of tax rules. The EU Member States should review and revise existing legislation according to this guidance. Therefore, a discussion on the normative can be extended from the countries involved in the case studies of the "open DOORS" project to Eropean level. This will allow facing some important challenges such as:

- bringing back the debate around the justification or elimination of entry barriers and the liberalization of certain economic sectors (such as the taxi sector) involving the sharing economy concept and its different actors. For this reason it is necessary to define new policies, new regulations and new approaches which engage the different actors of society.

- providing services that were previously unknown and therefore need to be analysed in depth. Since this is an enormously complex task, it is essential to differentiate between the uses that suppliers make of these platforms, whether they are intended to generate savings, profit or to improve the socialisation and sustainability by the environmental point of view.

It is important to have in mind that the core of the sharing economy is that different people are in touch building networks. For this reason "open DOORS" project decided to create the MedShare Network for Sharing and Collaborative Economy in the Mediterranean Area "to contribute to a smarter, more sustainable and more economically and socially inclusive Union" (https://open-doors.interreg-med.eu/news-events/news/detail/actualites/valencia-declaration-on-sharing-collabor ative-economy/).

\section{References}

Andersson, M., Hjalmarsson, A., \& Avital, M. (2013). Peer-to-Peer Service Sharing Platforms: Driving Share and Share Alike on a Mass-Scale. Association for Information Systems.

Andersson, M., Hjalmarsson, A., \& Avital, M. (2013). Peer-to-peer service sharing platforms: Driving share and share alike on a mass-scale. In International Conference of Information Systems 2013, Milan, Italy. Association for Information Systems.

Bachman, J. (2013). As trip planning moves online, AmEx's travel agents get bumped. BloombergBusinessweek. Retrieved from

http://www.businessweek.com/articles/2013-01-11/as-trip-planning-moves-online-amexs-travel-agents-getbumped

Benkler, Y. (2004). Sharing nicely: On shareable goods and the emergence of sharing as a modality of economic production. Yale Law Journal, 273-358. https://doi.org/10.2307/4135731

Berg, C., \& Fawn, F. (2016). How Brands Can Take Advantage of the Sharing Economy, 1-9. Retrieved from https://assets.cdn.sap.com/sapcom/docs/2016/01/66be5add-587c-0010-82c7-eda71af511fa.pdf

Berg, C., \& Fitter, F. (2016). Inquiry: How Brands Can Take Advantage of the Sharing Economy. 2016 SAP Center for Business Insight.

Botsman, R. (2015). Retrieved April 2016, from http://www.fastcoexist.com/3046119/defining-thesharing-economy-what-is-collaborative-consumption-andwhat-isnt/9

Candela, G., \& Figini, P. (2012). The economics of tourism destinations. New York, NY: Springer. https://doi.org/10.1007/978-3-642-20874-4

Cannon, B., \& Chung, H. (2015). A framework for designing co-regulation models well-adapted to technology-facilitated sharing economies. Santa Clara High Tech. L. J., 31, 23-97. 
Cervero, R., \& Tsai, Y. (2004). City CarShare in San Francisco, California second-year travel demand and car ownership impacts. Transportation Research Record, (1887), pp. 117-127.

Chaharbaghi, K., Fendt, C., \& Willis, R. (2003). Meaning, legitimacy and impact of business models in fast-moving environments. Management Decision, 41(4), 372-382. https://doi.org/10.1108/00251740310468013

Cho, M., Lee, K., Rim, C/ H., Goo, H. S., Park, C., \& Kim, H. J. (2013). Introduction Strategy of Inter-corporate Sharing Economy for Small Businesses Competitiveness Reinforcement. International Conference on Business Administration, 109-118. Retrieved from http://www.wseas.us/e-library/conferences/2014/Tenerife/ECONMATH/ECONMATH-16.pdf

Codagnone, C., \& Biagi, F. (2016). The Passions and the Interests: Unpacking the "Sharing Economy."

Codagnone, C., \& Martens, B. (2016). Scoping the Sharing Economy: Origins, Definitions, Impact and Regulatory Issues (No. JRC100369).

Cohen, A., Shaheen, S., \& McKenzie, R. (2008). Car Sharing: A Guide for Local Planners, Institute of Transportation Studies, University of California, Berkeley.

Cohen, M., \& Sundararajan, A. (2015). Self-Regulation and Innovation in the Peer-to-Peer Sharing Economy. The University of Chicago Law Review Dialogue, 82, 116-133.

Costain C., Ardron C. \& Habib K.N. (2012). Synopsis of users' behaviour of a carsharing program: A case study in Toronto. Transportation Research Part A: Policy and Practice, 46(3), 421-434. https://doi.org/10.1016/j.tra.2011.11.005

D'Andrea, A., Ferri, F., \& Grifoni, P. (2011). A Business Model Framework for Second Life. E-Novation for Competitive Advantage in Collaborative Globalization: Technologies for Emerging E-Business Strategie, pp. 34-47. IGI Publishing. https://doi.org/10.4018/978-1-60566-394-4.ch003

D'Andrea, A., Ferri, F., \& Grifoni, P. (2014). The e-commerce business model implementation. Encyclopedia of Business Analytics and Optimization, pp. 2509-2520, IGI Publishing. https://doi.org/10.4018/978-1-4666-5202-6.ch224

D'Andrea, A., Ferri, F., \& Grifoni, P. (2015). CBM: An Integrated Crowd-sourcing Business Model. Journal of Contemporary Management, 5(2), 47-58.

Daus, M., \& Russo, P. (2015). One Standard for All. Criminal Background Checks For Taxicab, For-Hire, And Transportation Network Company (Tnc) Drivers. New York: JayCollege of Criminal Justice, of the City University of New York. Retrieved from: http://www.utrc2.org/sites/default/files/pubs/Background Check Report.pdf(07-09-2015)

DeBare, I. (2008). Shared work spaces a wave of the future", San Francisco Chronicle, http://www.sfgate.com/cgi-bin/article.cgi?f=/c/a/2008/02/19/MN7CV2JFE.DTL. Economy. Minnesota Journal of Law, Science \& Technology, 16(1), 413-475.

European Commission. (2016). A European Agenda For The Collaborative Economy. Brussels.

Ferri, F., D'Andrea, A., \& Grifoni, P. (2012). IBF: An Integrated Business Framework for Virtual Communities in Journal of electronic commerce in organizations, 10(4), 1-13, IGI Global.

Ferri, F., Grifoni, P., \& Guzzo, T. (2008). Social Aspects of Mobile Technologies on Web Tourism Trend. Handbook of research on mobile business: technical, methodological and social perspectives, 293-303.

Ferri, F., Grifoni, P., \& Guzzo, T. (2013). Factors Determining Mobile Shopping. A Theoretical Model of Mobile Commerce Acceptance. International Journal of Information Processing \& Management, 4(7).

Focazio, M. T. (2001). The E-factor: Building a 24/7, Customer-centric, electronic business for the internet age. New York, NY: AMACOM.

Frenken, K., \& Schor, J. (2017). Putting the sharing economy into perspective. Environmental Innovation and Societal Transitions, 23, 3-10. https://doi.org/10.1016/j.eist.2017.01.003

Gata, J. (2015). The Sharing Economy, Competition and Regulation. CPI.

Gobble, M. M. (2015). Regulating Innovation in the New Economy. Research-Technology Management, March-April, 62-63. 
Gonzalez, A. G. (2003). PayPal and eBay: The legal implications of the $\mathrm{C} 2 \mathrm{C}$ electronic commerce model. In Proceedings of the 18th BILETA Conference: Controlling Information in the Online Environment. Retrieved from http://www.bileta.ac.uk/03papers/Guadamuz.html

Goudin, P. (2016). The Cost of Non-Europe in the Sharing Economy. European Parliamentary Research Service.

Gruszka, K. (2017). Framing the collaborative economy - Voices of contestation. Environmental Innovation and Societal Transitions, 23, 92-104. https://doi.org/10.1016/j.eist.2016.09.002

Guttentag, D. (2015) Airbnb: disruptive innovation and the rise of an informal tourism accommodation sector. Current Issues in Tourism, 18(12), 1192-1217. https://doi.org/10.1080/13683500.2013.827159

Guzzo, T., Ferri, F., \& Grifoni, P. (2014). Social influence analysis. In Encyclopedia of Social Network Analysis and Mining (pp. 1800-1807). Springer New York. https://doi.org/10.1007/978-1-4614-6170-8_186

Guzzo, T., Ferri, F., \& Grifoni, P. (2015). ECA: An E-commerce consumer acceptance model. International Business Research, 8(1), 145.

Guzzo, T., Ferri, F., \& Grifoni, P. (2016). A model of e-commerce adoption (MOCA): consumer's perceptions and behaviours. Behaviour \& Information Technology, 1-14. https://doi.org/10.1080/0144929X.2015.1132770

Hamari, J., Sjöklint, M., \& Ukkonen, A. (2015). The sharing economy: Why people participate in collaborative consumption. Journal of the Association for Information Science and Technology.

Hatzopoulos, V., \& Roma, S. (2017). Caring for sharing?. The collaborative economy under EU law. Common Market Law Review, 54(1), 81-127. Retrieved from http://www.kluwerlawonline.com/abstract.php?area=Journals\&id=COLA2017004

Huwer, U. (2004). "Public transport and car-sharing: benefits and effects of combined service". Transport Policy 11, 77-87. https://doi.org/10.1016/j.tranpol.2003.08.002

Investopedia.com. (2017). Sharing Economy Definition | Investopedia. Retrieved May 5, 2017, from http://www.investopedia.com/terms/s/sharing-economy.asp

John, N. A. (2013). The social logics of sharing. The Communication Review, 16(3), 113-131. https://doi.org/10.1080/10714421.2013.807119

Juman, D., \& Quinby, D. (2013). Traditional agencies reinvent themselves amid market shifts. The PhoCusWright Insider. Retrieved from http://insider.phocuswright.com/post/Traditional-Agencies-Reinvent-Themselves-Amid-Market-Shifts.aspx

Kalakota, R., \& Whinston, A. (1997). Electronic commerce: A managerial's guide. Reading, MA: Addison-Wesley.

Kaplan, R. S., \& Norton, D. P. (2004). Strategy maps: Converting intangible assets in to tangible outcomes. Boston, MA: Harvard Business School Press.

Katsev, R. (2003). 'Car Sharing: A New Approach to Urban Transportation Problems'. Analyses of Social Issues and Public Policy, 3(1), 65-86. https://doi.org/10.1111/j.1530-2415.2003.00015.x

Koopman, C., Mitchell, M. D., \& Thierer, A. D. (2015). The sharing economy and consumer protection regulation: The case for policy change. The Journal of Business, Entrepreneurship \& the Law, 8(2).

Koopman, C., Mitchell, M., \& Thierer, A. (2015). The Sharing Economy: Issues Facing Platforms, Participants, and Regulators.

Leforestier, A. (2009). The co-working space concept. CINE Term Project. Indian Institute of Management (IIMAHD), Ahmedabad.

Lonoff, S. J. (2014). Pros and Cons of Selling on Amazon, eBay and Etsy. http://www.upspringbaby.com/assets/images/press/cio.pdf

Madu, C. N., \& Madu, A. A. (2002). Dimensions of e-quality. International Journal of Quality \& Reliability Management, 19, 246-258. https://doi.org/10.1108/02656710210415668

Matofska, B. (2014). What is the Sharing Economy?' Retrieved 8 August 2014, from http://www.thepeoplewhoshare.com/blog/what-is-the-sharing-economy/

May, A., Ross T., Grebert J. \& Segarra G. (2008). User reaction to car share and lift share within a transport 'marketplace. IET Intelligent Transport Systems, 2(1), 47-60. https://doi.org/10.1049/iet-its:20070026 
McLean, S. (2015). The rise of the sharing economy. Computers \& Law Magazine of SCL, 26(1), 26-28.

Merkel, J. (2015). Coworking in the city. Ephemera, 15(1), 121.

Mills, P. K., \& Morris, J. H. (1986). Clients as "partial" employees of service organizations: Role development in client participation. Academy of management review, 11(4), 726-735.

Munkøe, M. M. (2017). Regulating the European Sharing Economy: State of Play and Challenges. Intereconomics, 52(1), 38-44. https://doi.org/10.1007/s10272-017-0641-3

Oei, S., \& Ring, D. (2015). Can Sharing Be Taxed? Boston: Boston College Law School Legal Studies Research Paper No. 352. Retrieved from SSRN: http://ssrn.com/abstract=2570584(17-8-2015)

PwC. (2015). The sharing economy. Retrieved 16 June 2015, from http://www.pwc.com/en_US/us/technology/publications/assets/pwc-consumer-intelligenceseries-the-sharing -economy.pdf

Ranchordas, S. (2015). Does Sharing Mean Caring? Regulating Innovation in the Sharing Economy.

Rauch, D., \& Schleicher, D. (2015). Like Uber, But For Local Government Policy: The Future of Local Regulation of the "Shared Economy". New York New York University, Marron Institute of Urban Management, Working Paper \# 21.

Rifkin, J. (2011). The Third Industrial Revolution, Palgrave MacMillan.

Rozin, R. S. (2004). Buyers in business-to-business branding. Journal of Brand Management, 11, 344-345. https://doi.org/10.1057/palgrave.bm.2540179

Schor, J. (2014). Debating the Sharing Economy.

Shaheen, S., Sperling, D., \& Wagner, C. (2001). Carsharing in Europe and North American: past, present, and future. University of California Transportation Center.

Smith, A. (2016). Shared, Collaborative and On Demand: The New Digital Economy (Vol. 19). Retrieved from http://www.pewinternet.org/files/2016/05/PI_2016.05.19_Sharing-Economy_FINAL.pdf

Stevenson, A. (2010). Oxford dictionary of English. Oxford University Press.

Sundararajan, A. (2013). From Zipcar to the Sharing Economy. Harvard Business Review.

Sunil, J., \& Noah, Z. (2015). Policymaking for the Sharing Economy: Beyond Whack-A-Mole. Toronto: Mowat Centre, University of Toronto. Retrieved from http://mowatcentre.ca/wp-content/uploads/publications/106_PolicymakingForTheSharingEconomy.pdf(205-2015)

The Economist. (2013). The rise of the sharing economy. Retrieved from http://www.economist.com/news/leaders/21573104-internet-every-thing-hire-rise-sharing-economy

Timmers, P. (1999). Electronic commerce: Strategies and models for business-to-business trading. New York, NY: John Wiley \& Sons.

Turban, E., Mclean, E., Wetherbe, J., Bolloju, N., \& Davison, R. (2002). Information technology management: Transforming business in the digital economy. New York, NY: John Wiley \& Sons.

Weill, P., \& Vitale, M. R. (2001). Place to space: Migrating to eBusiness.

With, J. O., Tran, C., \& Silva, C. (2013). The Collaborative Economy. Retrieved from http://www.collaboriamo.org/media/2014/04/collabecon-draft16-130531132802-phpapp02-2.pdf

Wosskow, D. (2014). Unlocking the sharing economy: An independent review. London: UK Department for Business, Innovation and Skills.

Zrenner, A. (2015).The ethics of regulating the Sharing Economy. The Kenan Institute for Ethics at Duke University.

\section{Copyrights}

Copyright for this article is retained by the author(s), with first publication rights granted to the journal.

This is an open-access article distributed under the terms and conditions of the Creative Commons Attribution license (http://creativecommons.org/licenses/by/4.0/). 